Archived version from NCDOCKS Institutional Repository http://libres.uncg.edu/ir/asu/

\title{
Appalachlyan
}

$\overline{\text { B O O N E, N O R T H C A R O L I N A }}$

\section{Analyses of Intrinsic Water-Use Efficiency Indicate Performance Differences of Ponderosa Pine and Douglas-fir in Response to CO2 Enrichment}

\author{
By: Peter T. Soule \& Paul A. Knapp
}

\begin{abstract}
Aim Increasing intrinsic water-use efficiency (iWUE) in trees is a global-scale response to increasing levels of atmospheric carbon dioxide $(\mathrm{Ca})$. Our primary goal was to determine whether significant differences in either iWUE or radial growth exist between locally co-occurring ponderosa pine (Pinus ponderosa var. ponderosa; PIPO) and Douglas-fir (Pseudotsuga menziesii var. glauca; PSME) trees growing in minimally disturbed environments and exposed to gradually increasing levels of $\mathrm{Ca}^{*} \neg \neg$

Methods We developed 14 tree-ring chronologies, calculated basal area increment (BAI) and examined stable carbon isotope ratios ( $\mathrm{d} 13 \mathrm{C})$ contained in the tree cores to determine: (1) the consistency of climate/ BAI responses and iWUE between the two species and the magnitude of climate change for the primary drivers of BAI; (2) changes in iWUE and BAI values during ad 1850-present; and (3) the extent of panregional consistency in iWUE, BAI and climatic responses.

Results PIPO and PSME experienced exponentially increasing iWUE rates during ad 1850-present suggesting either increased net photosynthesis or decreased stomatal conductance, or both. There was panregional consistency, with similar temporal trends in iWUE and climate/growth relationships between species. Both species experienced above-average BAI in the latter half of the 20th century despite no favourable changes in climate. We found substantive differences between species as PIPO has experienced greater increases in iWUE and BAI relative to PSME. The trends in BAI and iWUE were significantly correlated for PIPO, but not for PSME.

Main conclusions Differential radial growth and iWUE responses exist among co-occurring species and are most pronounced during the period of highest Ca. As PIPO and PSME forests have extensive geographical ranges and are critical to North American forestry, any substantive change in forest dynamics related to water use and growth may have ecological and economic implications.
\end{abstract}

Peter T. Soule \& Paul A. Knapp (2015) "Analyses of Intrinsic Water-Use Efficiency Indicate Performance Differences of Ponderosa Pine and Douglas-fir in Response to CO2 Enrichment" Journal of Biogeography Volume 42 pp. 144-155 Version of Record Available From (www.onlinelibrary.wiley.com) 


\section{Introduction}

Atmospheric carbon dioxide $(\mathrm{Ca})$ concentrations reached 400 ppmv in 2014, representing an approximately $80 \mathrm{ppmv}$ increase since direct measurements began in 1958 (Keeling et al., 2001) and the highest level during the past 800,000 years (L€uthi et al., 2008). An influence of rising $\mathrm{Ca}$ on intrinsic water-use efficiency (iWUE; the ratio between

net photosynthesis and stomatal conductance) in trees is the narrowing of leaf stomatal apertures, thus reducing transpi-ration rates and increasing the efficiency of soil-moisture usage (Tognetti et al., 1998). In a meta-study synthesizing results from 20 different locations in four biomes and 19 tree different species, $\mathrm{Pe}^{\sim}$ nuelas et al. (2011) found positive changes in iWUE, ranging from $5.6 \%$ to $36.2 \%$ from the 1960 s to the 2000s. The effect of elevated $C_{a}$ can either indi-rectly (Pe nuelas et al., 2011) or directly affect radial growth of trees. Indirect effects of increased iWUE include an exten-sion to the growing season where soil moisture is limiting in late summer (Tyson et al., 2002; Soul'e \& Knapp, 2013) and/or increased growth during drought periods (Wullschleger et al., 2002; Soul'e \& Knapp, 2011). The effects of increased iWUE can be age-specific, with older trees preferentially ben-efitting (Knapp \& Soul'e, 2011). The direct effects of elevated $C_{a}$ occur through increased rates of net photosynthesis (Morgan et al., 2004).

Despite a positive relationship between radial tree growth and increasing $C_{a}$, not all species have experienced growth increases commensurate with increases in iWUE (Pe nuelas et al., 2008, 2011; Gedalof \& Berg, 2010; Silva et al., 2010; Wang et al., 2012), suggesting either a limited benefit or the primacy of factors masking an iWUE effect. Trees respond to multiple environmental stimuli (Fritts, 1976) and site-specific radial growth declines have been attributed to increasing temperature (Salzer et al., 2009; Silva et al., 2010), drought (Linares \& Camarero, 2012; Wang et al., 2012), insect attacks (Speer et al., 2001; Speer \& Holmes, 2004; Knapp et al., 2013), pathogens (Stanton, 2007) and atmospheric pollution (Adams et al., 1985).

Responses to both water stress ( $\mathrm{Pi}^{\sim}$ nol \& Sala, 2000; Stout \& Sala, 2003; Marshall \& Monserud, 2006) and $C_{a}$ enrich-ment vary among tree species (Gedalof \& Berg, 2010; And-reu-Hayles et al., 2011; Dawes et al., 2011). $\mathrm{C}_{\mathrm{a}}$ enrichment

Figure 1 Common conditions for cooccurring ponderosa pine (Pinus ponderosa var. ponderosa; PIPO); and Douglas-fir (Pseudotsuga menziesii var. glauca; PSME) trees at 14 study sites in the northern Rocky Mountains, USA. The two nearest trees are PSME (left) and PIPO (right centre). They are growing within an open canopy ecosystem at Ferry Landing Research Natural Area (FLR/FLD). can ameliorate moisture stress in woody plants (e.g. Idso \& Idso, 1994; Wullschleger et al., 2002; Huang et al., 2007; Soulé \& Knapp, 2011, 2013; Koutavas, 2013), thus the question arises of whether co-occurring tree species experiencing near-identical climatic and topoedaphic conditions respond differently. In the northern Rockies, two dominant tree species, ponderosa pine (Pinus ponderosa var. ponderosa; PIPO) and Douglas-fir (Pseudotsuga menziesii var. glauca; PSME), have similar ranges (Earle, 2013), frequently co-occur (Fig. 1) and have great ecological and economic value (WWPA, 2013). However, interspecific comparison of the responses of PIPO and PSME to water stress in the northern Rockies has shown that while PIPO is more vulnerable to xylem cavitation, PIPO has higher xylem conductance because of higher stomatal control (Piñol \& Sala, 2000; Stout \& Sala, 2003). The few studies of long-term responses of PSME and PIPO to elevated $\mathrm{C}_{\mathrm{a}}$ exhibit mixed results (e.g. Marshall \& Monserud, 1996; Feng, 1999) and require further investigation. Here, we posit that PIPO may preferentially benefit from increasing iWUE because of its inherent physiological characteristics.

Our work represents a previously unexplored aspect of the relationship between iWUE and tree growth. We confine our analyses to trees growing in areas that have been subjected to minimal human interference and exposed to gradual increases in $\mathrm{C}_{\mathrm{a}}$. By sampling locally co-occurring tree species, we minimized the effects of exogenous factors including microclimate and topoedaphic conditions that might mask otherwise significant growth differences between species. Thus, examining radial-growth rates and iWUE temporal trends of co-occurring PSME and PIPO may offer insights regarding species-specific responses to increasing $C_{a}$ levels. Our primary goal was to determine whether significant differences existed in either iWUE or radial growth (measured via basal area increment, BAI) between locally co-occurring

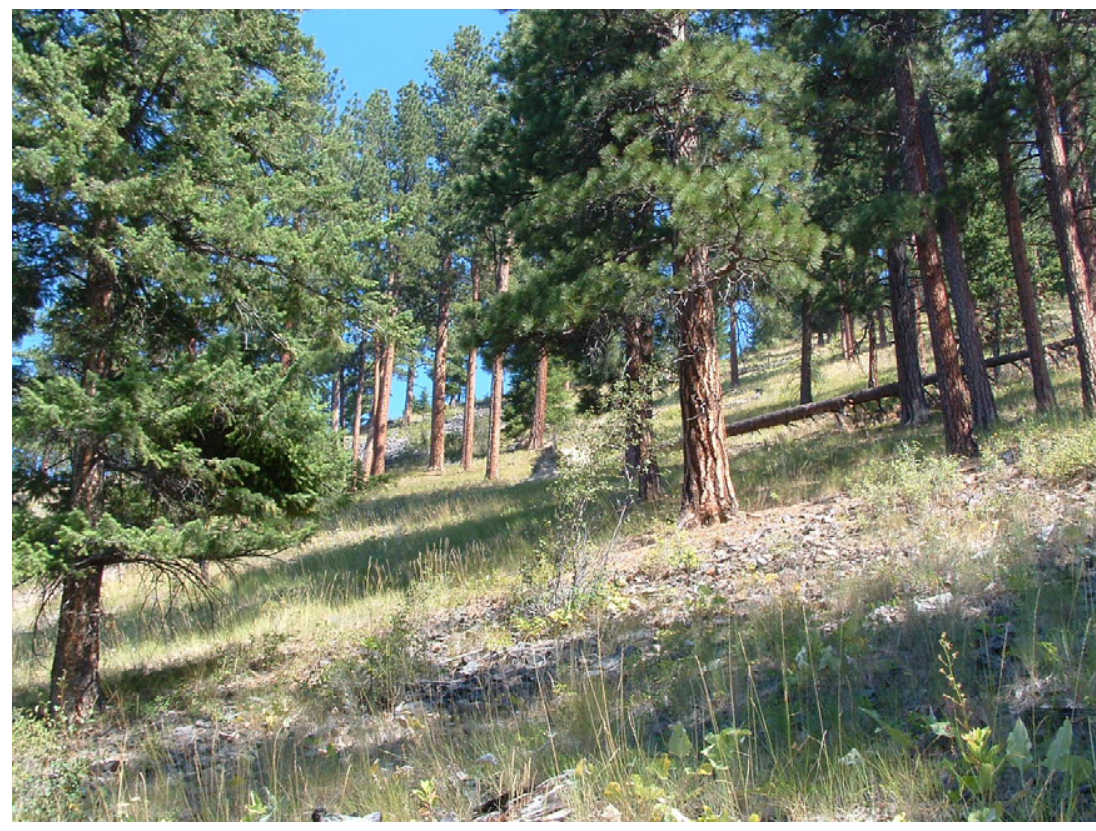


ponderosa pine (PIPO) and Douglas-fir (PSME) trees growing in minimally disturbed environments and exposed to gradually increasing levels of $\mathrm{C}_{\mathrm{a}}$. Our specific objectives were: (1) to examine the consistency of climate/BAI responses and iWUE between species and the magnitude of climate change for the primary drivers of BAI; (2) to determine the magnitude of changes in iWUE and BAI values during AD 1850present; and (3) to determine the extent of pan-regional consistency in iWUE, BAI and climatic responses.

\section{MATERIALS AND METHODS}

\section{Fieldwork}

We collected tree-ring data from seven sites within the boundaries of the United States Forest Service Northern Rockies Region (FSNRR) (Fig. 2, Table 1). Each collection site has stands with co-occurring PIPO and PSME. We selected study sites that minimized potential anthropogenic influences on radial growth. Three of the sites have a Research Natural Area (RNA) designation [BCR/BCD, FLR/ FLD and WCR/WCD (where R = ponderosa pine chronology and $\mathrm{D}=$ Douglas-fir)] and are noted for their ecological significance and minimal anthropogenic impacts (Evenden et al., 2001). The remaining four sites were chosen based on a history of minimal human influence associated with factors such as topographic isolation and land-use history. All sites are in either northern interior Idaho or western Montana: locations where the potential radial growth impacts of either ozone or nitrogen are minimized because of low exposure (Lee \& Hogsett, 2001).
Our criteria for tree selection were designed to further reduce confounding influences on growth. We selected trees in open-canopy environments to minimize potential growth changes from canopy infilling and neighbouring tree senescence. We avoided sampling trees with visible signs of damage from fire or lightning, abnormal growth forms, or with visible signs of pathogens [e.g. pitch tubes associated with mountain pine beetle (Dendroctonus ponderosae) outbreaks, and dwarf mistletoe (Arceuthobium spp.)]. At each site we non-destructively obtained two or more core samples at approximately $1.4 \mathrm{~m}$ height from $30-40$ mature PIPO and PSME trees using standard dendrochronological techniques (Phipps, 1985).

\section{Tree-ring data processing and basal area increment}

We sanded each core sample until the cellular structure of the rings was visible and cross-dated the samples using the list method (Yamaguchi, 1991). We used linear encoders to measure ring widths to $0.001 \mathrm{~mm}$ precision and examined the measured data using COFECHA (Holmes, 1983; GrissinoMayer, 2001) to ensure the dating accuracy. For analysis, we selected a subsample of 12 cores per species per site from our original sample of 30-40 cores/species/site. Each subsample was based on the criteria (Soulé \& Knapp, 2011) of selecting two cores from each of six trees that had welldefined ring structure, strong correlations with the full chronology and multi-century longevity (mean age $>225$ years; Table 1).

For each core we calculated annual basal area increment (BAI) values via Silva et al. (2010):

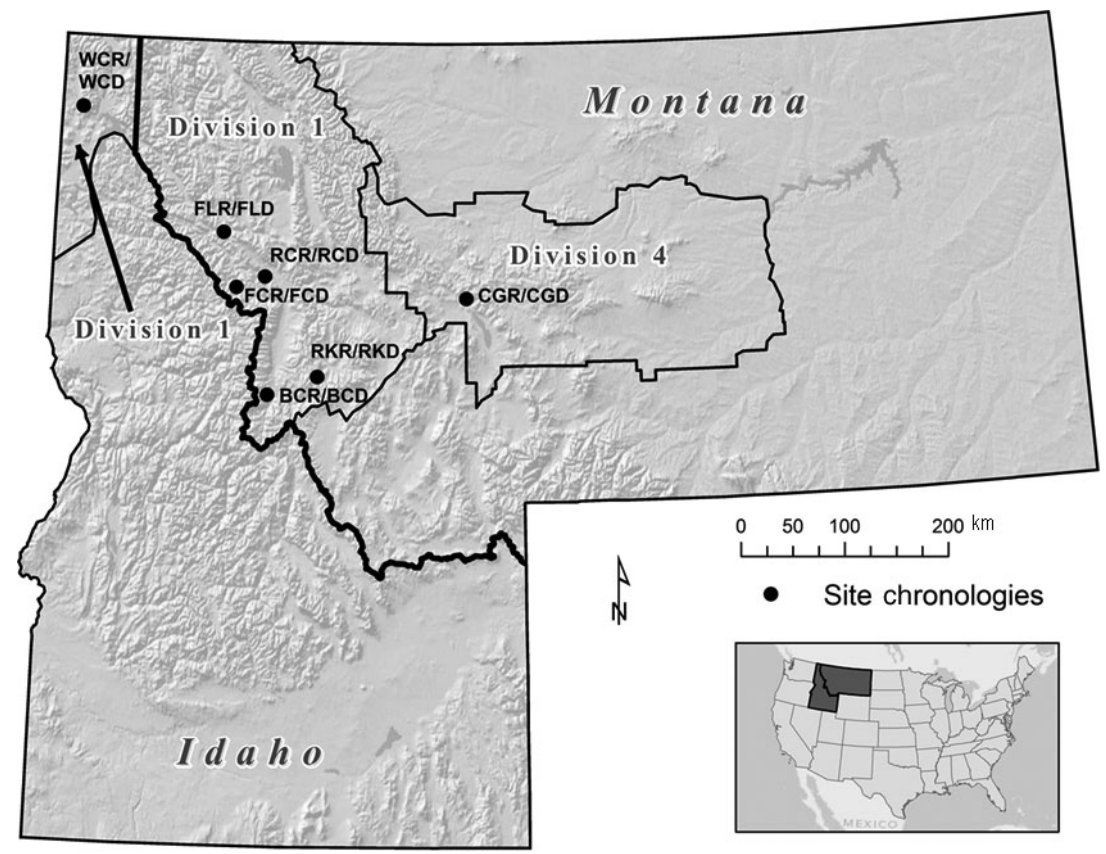

Figure 2 Location of the 14 study sites in the northern Rocky Mountains (Montana and Idaho), USA, including climate division boundaries. Reprinted from Soulé \& Knapp (2013) with permission from Elsevier. 
Table 1 Details for tree-ring chronologies ( $n=12$ samples in each chronology) collected from co-occurring ponderosa pine (Pinus ponderosa var. ponderosa) and Douglas-fir (Pseudotsuga menziesii var. glauca) trees in the northern Rocky Mountains, USA.

\begin{tabular}{|c|c|c|c|c|c|c|}
\hline Site & Interseries correlation $^{\mathrm{a}}$ & Mean sensitivity ${ }^{\mathrm{b}}$ & AR1 correlation ${ }^{c}$ & $\%$ absent rings ${ }^{\mathrm{d}}$ & Complete dates $(\mathrm{AD})^{\mathrm{e}}$ & Mean age of trees (years $)^{\mathrm{f}}$ \\
\hline \multicolumn{7}{|c|}{ Wellner Cliffs Research Natural Area, Idaho } \\
\hline $\mathrm{WCR}^{\mathrm{g}}$ & 0.557 & 0.249 & 0.73 & 0.441 & $1653-2009$ & 335 \\
\hline WCD & 0.572 & 0.231 & 0.642 & 0.498 & $1673-2009$ & 283 \\
\hline \multicolumn{7}{|c|}{ Ferry Landing Research Natural Area, Montana } \\
\hline FLR & 0.607 & 0.257 & 0.542 & 0.052 & $1560-2004$ & 318 \\
\hline FLD & 0.678 & 0.266 & 0.515 & 0 & $1690-2006$ & 240 \\
\hline \multicolumn{7}{|c|}{ Rock Creek West, Montana } \\
\hline RCR & 0.650 & 0.281 & 0.647 & 0.062 & $1602-2006$ & 266 \\
\hline $\mathrm{RCD}$ & 0.734 & 0.251 & 0.516 & 0.037 & $1757-2006$ & 227 \\
\hline \multicolumn{7}{|c|}{ Fish Creek, Montana } \\
\hline FCR & 0.534 & 0.246 & 0.503 & 0.189 & $1710-2006$ & 220 \\
\hline FCD & 0.707 & 0.227 & 0.452 & 0.060 & $1611-2006$ & 277 \\
\hline \multicolumn{7}{|c|}{ Rock Creek East } \\
\hline RKR & 0.669 & 0.286 & 0.496 & 0.055 & $1541-2008$ & 301 \\
\hline RKD & 0.744 & 0.302 & 0.454 & 0 & $1672-2008$ & 269 \\
\hline \multicolumn{7}{|c|}{ Boulder Creek Research Natural Area, Montana } \\
\hline BCR & 0.618 & 0.261 & 0.523 & 0.088 & $1650-2004$ & 282 \\
\hline $\mathrm{BCD}$ & 0.538 & 0.218 & 0.485 & 0.022 & $1307-2008$ & 374 \\
\hline \multicolumn{7}{|c|}{ Cabin Gulch Research Natural Area, Montana } \\
\hline CGR & 0.675 & 0.367 & 0.472 & 1.241 & $1634-2009$ & 301 \\
\hline CGD & 0.667 & 0.437 & 0.447 & 0.708 & $1674-2009$ & 247 \\
\hline
\end{tabular}

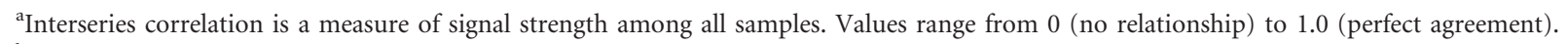

${ }^{\mathrm{b}}$ Mean sensitivity is a measure of interannual variation in ring-widths. Higher values represent greater year-to-year variation.

${ }^{c}$ Autoregression coefficient for time $=-1$ from ARSTAN with no detrending.

$\mathrm{d}_{\%}(0-100)$ absent rings is a measure of the frequency of years in which trees did not produce an annual ring. It is a surrogate measure of environmental stress.

${ }^{\mathrm{e}}$ The calendar year for the oldest core in the sample and the common ending year for the BAI sample.

${ }^{\mathrm{f}}$ Mean age of the $n=12$ cores in each sample.

${ }^{\mathrm{g}} \mathrm{XXR}=$ ponderosa pine chronology, $\mathrm{xxD}=$ Douglas-fir chronology.

$$
\mathrm{BAI}=\pi\left(R_{n}^{2}-R_{n-1}^{2}\right)
$$

where $R$ is tree radius and $n$ is year. To match with iWUE values, we then calculated pentadal means for BAI. We excluded from our analyses all data prior to 1850 to avoid the 'juvenile effect' (McCarroll \& Loader, 2004) associated with iWUE calculations. The first pentad includes data from 1850 to 1854 , the last complete pentad for all sites was 2000-2004, and the final pentad (2005) has means based on a varying number of years of radial growth per site (Table 1). As our sampling was focused on older trees that often produce narrow $(<0.5 \mathrm{~mm})$ annual rings that can bias results when radial growth rates are standardized (Cook \& Peters, 1997), we based our analyses on BAI, an absolute measure of radial growth.

\section{Isotopic analysis and determination of iWUE}

We examined stable carbon isotope ratios $\left(\delta^{13} \mathrm{C}\right)$ contained in the tree cores to determine the extent of physiological changes incurred by PSME and PIPO since 1850 during rising $\mathrm{C}_{\mathrm{a}}$ conditions. All tree species have $\mathrm{C}_{3}$ photosynthetic pathways that discriminate against the heavier ${ }^{13} \mathrm{C}$ isotope as they preferentially assimilate ${ }^{12} \mathrm{C}_{\mathrm{a}}$ during photosynthesis (i.e. photosynthetic discrimination); thus, $\delta^{13} \mathrm{C}$ values are lower in tree tissue compared to ambient air. Correcting for changes in $\delta^{13} \mathrm{C}$ of the atmosphere provides a better measure of photosynthetic discrimination $(\Delta)$ and is linearly related to the ratio of intercellular to ambient $\mathrm{C}_{\mathrm{a}}$ concentrations (Farquhar et al., 1989), which are variables required to determine iWUE. Photosynthetic discrimination is also affected by soil moisture availability as stomata narrow during drought periods thereby decreasing $\Delta$ and, in turn, increasing iWUE (e.g. Zhang \& Marshall, 1994). Thus, changes in iWUE for each species should reflect centennial-length increases associated with rising $\mathrm{C}_{\mathrm{a}}$ coupled with shorter-term fluctuations caused by above/below-average soil moisture conditions.

Isotopic analysis from wood cellulose of complete rings was performed by the Environmental Isotope Laboratory (EIL) of the Department of Geosciences at the University of Arizona. The EIL used standard procedures (Sternberg, 1989; Leavitt \& Danzer, 1993; Coplen, 1996) to process the samples, and returned to us pentadal values of carbon isotope composition $\left(\delta^{13} \mathrm{C}\right)$, which we then used to calculate pentadal values of iWUE via (Ehleringer \& Cerling, 1995):

$$
\mathrm{iWUE}=A / g=\left(c_{\mathrm{i}} / c_{\mathrm{a}}\right) 0.625
$$

where iWUE $(\mu \mathrm{mol} / \mathrm{mol})$ measures the $\mathrm{CO}_{2}$ assimilation of the tree $(A)$ relative to stomatal conductance through the 
leaf $(g) ; c_{\mathrm{i}}$ is intercellular $\mathrm{CO}_{2}$; and $c_{\mathrm{a}}$ is $\mathrm{CO}_{2}$ in the atmosphere. Details on the exact procedures employed to obtain end values of iWUE are outlined by Knapp \& Soulé (2011).

\section{Statistical analysis}

For BAI, we began with the $n=12$ sample of cores and calculated annual values. Per established procedures in dendrochronological research (Fritts, 1976), we used two cores/tree as this minimizes within-tree variance. We then averaged values for 5-year periods to obtain pentadal measurements (e.g. 1850 pentad $=1850-1854)$ and averaged the pentadal values across all sites to obtain the seven-site means. We then obtained standardized scores ( $z$-scores) from the pentadal averages and used the standardized values in further testing, as our goal was to determine relative differences in radial growth between species and through time as opposed to absolute differences. Similarly, for iWUE we averaged the pentadal values across all sites to obtain the seven-site means. We used matched-pairs Wilcoxon tests on standardized pentadal BAI values for the seven study sites and for the seven-site means to determine whether significant differences in radial growth exist between PIPO and PSME at each site and for regional averages. We used spss version 20 for all statistical analyses. For iWUE, we assessed betweenspecies similarities via Spearman correlation, as both the raw data and transformed data (e.g. $\log _{10}$, natural $\log$ ) were not normally distributed. We used Spearman correlation between BAI/iWUE values and pentad to determine whether temporal trends existed and to determine the degree of association between BAI and iWUE. As not all variables examined were normally distributed or had linear relationships (i.e. iWUE and time), we used nonparametric techniques for consistency. To determine whether differences between species had changed through time we used the seven-site mean and calculated the pentadal ratio of standardized PIPO BAI to standardized PSME BAI. For iWUE we did the same using the raw values for the seven-site means. We examined the pentadal patterns graphically and determined whether temporal trends in the ratios existed using Spearman correlation.

We examined the climatic response of radial growth using Spearman correlation between a suite of monthly, seasonal and annual measures of temperature, precipitation, and drought severity as measured by the Palmer drought severity index (PDSI; Palmer, 1965) compared to annual BAI data. We used climate-division data from 1905 to the end of the BAI record (Table 1, Fig. 2). After identifying the primary climatic driver of radial growth for PIPO and PSME at each study site (e.g. July drought severity), we determined whether long-term (1905-end of record; Table 1) temporal trends were present using Spearman correlation. We also addressed potential changes in climate that might impact radial tree growth by determining whether conditions have become significantly wetter/drier in the post-1950 period relative to pre-1950s by testing the primary climatic drivers of radial growth for significant differences pre- and post-1950 using Wilcoxon tests.

\section{RESULTS}

Radial growth of both PIPO and PSME is positively associated with moisture availability, either directly through supply (e.g. May-July precipitation) or through supply and demand as measured by the PDSI (Table 2). None of the monthly/seasonal/lagged temperature variables were the most significant climatic factors for radial growth, but the strongest associations ( $r_{s}$ value range -0.2 to -0.47 with $\left.n=101-104\right)$ all involved some aspect of summer temperature and were negatively and significantly $(P<0.05)$ related to radial growth. The only significant $(P<0.05)$ long-term temporal trend for any of the primary climatic drivers for radial growth (Table 2) occurred in Montana Climate Division 4 (CGR and CGD study sites; Fig. 2), where negative trends in PDSI values of the previous-year November to the current-year August indicate a shift towards increasing aridity. The primary climatic driver of radial growth at WCR (previous-September PDSI) was significantly different in the post-1950 period, with wetter conditions experienced. All other comparisons of pre- to post1950 conditions revealed there were no significant changes in the climatic conditions most closely associated with radial growth. The lack of meaningful long-term climate change for radial tree growth in the region is demonstrated by plots showing mean May to July values of temperature and precipitation for the three climate divisions (Fig. 3).

The Wilcoxon tests indicated that no significant $(P>0.05)$ differences existed in radial growth as measured by standardized BAI between PIPO and PSME for each of the seven study-site pairs. However, differences in BAI among sites exist, with six chronologies showing strong positive temporal trends, five no trends and three with a negative trend (Table 3, Fig. 4a-g). Only one clear match exists between long-term trends in radial growth and changing climatic conditions. The long-term and significant $(P<0.001)$ trend of reduced radial growth at CGD (negative but non-significant at CGR) matches the long-term trend for drier conditions within Montana Climate Division 4 (Table 3, Fig. 4b). At WCR/WCD in Idaho Climate Division 1 the climatic drivers of radial growth have no long-term trend, but there has been a shift towards wetter conditions post-1950 (significant for WCR) that would be conducive to increased tree growth (Table 2). Long-term trends of BAI are positive at WCR and significantly upward at WCD (Table 3).

For the seven-site means by species, PIPO growth increased significantly, while PSME growth was non-significant (Table 3). The seven-site means for PIPO BAI and PSME BAI are similar $\left(r_{\mathrm{s}}=0.701, \quad P<0.001, \quad n=32\right.$; Fig. $4 \mathrm{~h})$, but there is a strong trend in the multi-site PIPO/ PSME ratio $\left(r_{\mathrm{s}}=0.531, P<0.01, n=32\right.$; Fig. 5$)$ suggesting that, for the region as a whole, PIPO trees have grown at greater rates since the mid-20th century. During 1950 until 
Table 2 The strongest relationships (1905-end of record) between annual basal area increment (BAI) from ponderosa pine (Pinus ponderosa var. ponderosa) and Douglas-fir (Pseudotsuga menziesii var. glauca) trees and a climate variable representing drought severity (Palmer drought severity index, PDSI) and precipitation at each study site (northern Rocky Mountains, USA) based on Spearman correlation; test for temporal trends for the main climate driver of radial tree growth via Spearman correlation; and Wilcoxon test for difference in the main climate driver of radial tree growth for years pre- and post-1950 (see Table 1 for complete study site names and chronology details).

\begin{tabular}{|c|c|c|c|}
\hline Study sites & $\begin{array}{l}\text { Relationship between BAI w/climate } \\
{\left[r_{\mathrm{s}} \text {, variable }(n ; P \text {-value })\right]}\end{array}$ & $\begin{array}{l}\text { Temporal trend for main climate } \\
\text { driver of radial tree growth } \\
\text { (climate w/time) }\left[r_{\mathrm{s}}(n ; P \text {-value })\right]\end{array}$ & $\begin{array}{l}\text { Wilcoxon test for difference in } \\
\text { main climate driver of tree } \\
\text { growth (pre- vs. post } 1950) \\
{[P \text {-value }(n \text { early, } n \text { late })]}\end{array}$ \\
\hline \multicolumn{4}{|c|}{ Sites in Idaho Climate Division 1} \\
\hline WCR & 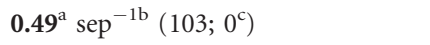 & $0.11(104 ; 0.25)$ & $\mathbf{0 . 0 2 8}(44,54)$ \\
\hline WCD & $\mathbf{0 . 4 4}$ jun $(104 ; 0)$ & $0.16(104 ; 0.112)$ & $0.074(45,54)$ \\
\hline \multicolumn{4}{|c|}{ Sites in Montana Climate Division 1} \\
\hline FLR & 0.49 oct $^{-1}$-aug $(99 ; 0)$ & $-0.1\left(103^{\mathrm{d}} ; 0.302\right)$ & $0.258\left(45,58^{\mathrm{e}}\right)$ \\
\hline FLD & $\mathbf{0 . 4 1}$ jun $(101 ; 0)$ & $-0.09(103 ; 0.393)$ & $0.264(45,58)$ \\
\hline RCR & $\mathbf{0 . 5 4}$ jul $(101 ; 0)$ & $-0.09(103 ; 0.373)$ & $0.393(45,58)$ \\
\hline $\mathrm{RCD}$ & 0.49 mjjPPT (101;0) & $0(103 ; 0.976)$ & $0.525(45,58)$ \\
\hline FCR & 0.21 oct $^{-1}(101 ; 0.032)$ & $-0.07(103 ; 0.516)$ & $0.378(45,58)$ \\
\hline FCD & $\mathbf{0 . 4 4} \mathrm{sep}^{-1}(101 ; 0)$ & $-0.05(103 ; 0.645)$ & $0.347(45,58)$ \\
\hline RKR & $\mathbf{0 . 6 2}$ jul $(103 ; 0)$ & $-0.09(103 ; 0.373)$ & $0.393(45,58)$ \\
\hline RKD & 0.54 jun $(103 ; 0)$ & $-0.09(103 ; 0.393)$ & $0.264(45,58)$ \\
\hline BCR & 0.49 mjjPPT (99; 0) & $0(103 ; 0.976)$ & $0.525(45,58)$ \\
\hline $\mathrm{BCD}$ & 0.46 mjjPPT (103; 0) & $0(103 ; 0.976)$ & $0.525(45,58)$ \\
\hline \multicolumn{4}{|c|}{ Sites in Montana Climate Division 4} \\
\hline CGR & 0.53 nov $^{-1}$-aug $(103 ; 0)$ & $-0.36(103 ; 0)$ & $0.68(44,59)$ \\
\hline CGD & 0.69 nov $^{-1}$-aug $(103 ; 0)$ & $-0.36(103 ; 0)$ & $0.68(44,59)$ \\
\hline
\end{tabular}

${ }^{\mathrm{a}}$ Boldfaced correlations are significant with $P<0.05$.

${ }^{\mathrm{b}}$ Variable acronyms (sep = September, jun = June, etc.; superscript -1 indicates variable is lagged by one year; mjj = average of May to July; PPT indicates monthly precipitation, all other variables represent drought severity as measured by PDSI values).

${ }^{\mathrm{c}} P$-values out to three decimal places.

${ }^{\mathrm{d}, \mathrm{e}}$ For consistency, we used the climate record through 2008 for all sites for the test of climate trends and differences for sites in Montana Climate Division 1.

the end of the record - a period when $\mathrm{C}_{\mathrm{a}}$ concentrations rapidly increased - six of the seven PIPO sites had $>50 \%$ of pentadal BAI values $>0$, and FCR did not experience a single pentadal value of $<0$ (Fig. $4 \mathrm{a}-\mathrm{g}$ ). For PSME, four of the seven sites had more than half of the pentads with positive BAI values since 1950 (Fig. 4a-g).

Temporal patterns of iWUE for PIPO and PSME are in-phase (Fig. 6a-h). All sites and the seven-site means have significant $(P<0.001)$ positive associations between PSME and PIPO, with $r_{\mathrm{s}}$ values ranging from 0.728 at WCR/WCD to 0.981 for the seven-site mean. At all sites and for the seven-site means, there are strong, positive, nonlinear temporal trends (1850-end of record) for iWUE for both species (Table 3, Fig. 6a-h). Except for WCR and WCD, iWUE values are consistently higher for PSME than for PIPO. However, there is a notable shift in iWUE between species for the multi-site mean conditions, with smaller differences in iWUE between PIPO and PSME occurring with time ( $r_{\mathrm{s}}=0.521, P<0.01, n=32$; Fig. $6 \mathrm{~h}$ ), indicating greater iWUE increases for PIPO. Changes in iWUE ratios between PIPO and PSME are most marked post-1970 (Fig. 5).

The association between BAI and iWUE for individual sites is mixed, with two PIPO and three PSME sites having a significant positive association $(P<0.05)$ between BAI and iWUE, and one PIPO and two PSME sites with a significant
$(P<0.01)$ negative association (Table 3$)$. The association between BAI and iWUE for the seven-site mean is significant for PIPO $\left(r_{\mathrm{s}}=0.586, P<0.001, n=32\right)$, but insignificant for PSME $\left(r_{\mathrm{s}}=0.197, P=0.279, n=32\right)$. A positive and significant association also exists between the BAI and iWUE ratios for PIPO/PSME during 1850-2005 $\quad\left(r_{\mathrm{s}}=0.515\right.$, $P=0.003, n=32$ ) (Fig. 5).

\section{DISCUSSION}

The significant associations between BAI and climate identified during late spring to summer (e.g. July PDSI values, May-July precipitation) or the previous-year autumn (e.g. previous-September PDSI) indicate that radial growth for PSME and PIPO is affected by moisture supply and demand during the growing season of the current and previous year (Table 2). These results, based on an absolute measure of radial growth (BAI), are similar to those found by Soule \& Knapp (2013) at the same study sites when using a larger sample of trees to compare standardized values of radial growth with climate. PIPO and PSME are responding to climate, both on an annual basis (Table 2), and within extended periods either favourable or unfavourable for growth. For example, all sites experienced low radial growth concurrent with extended 

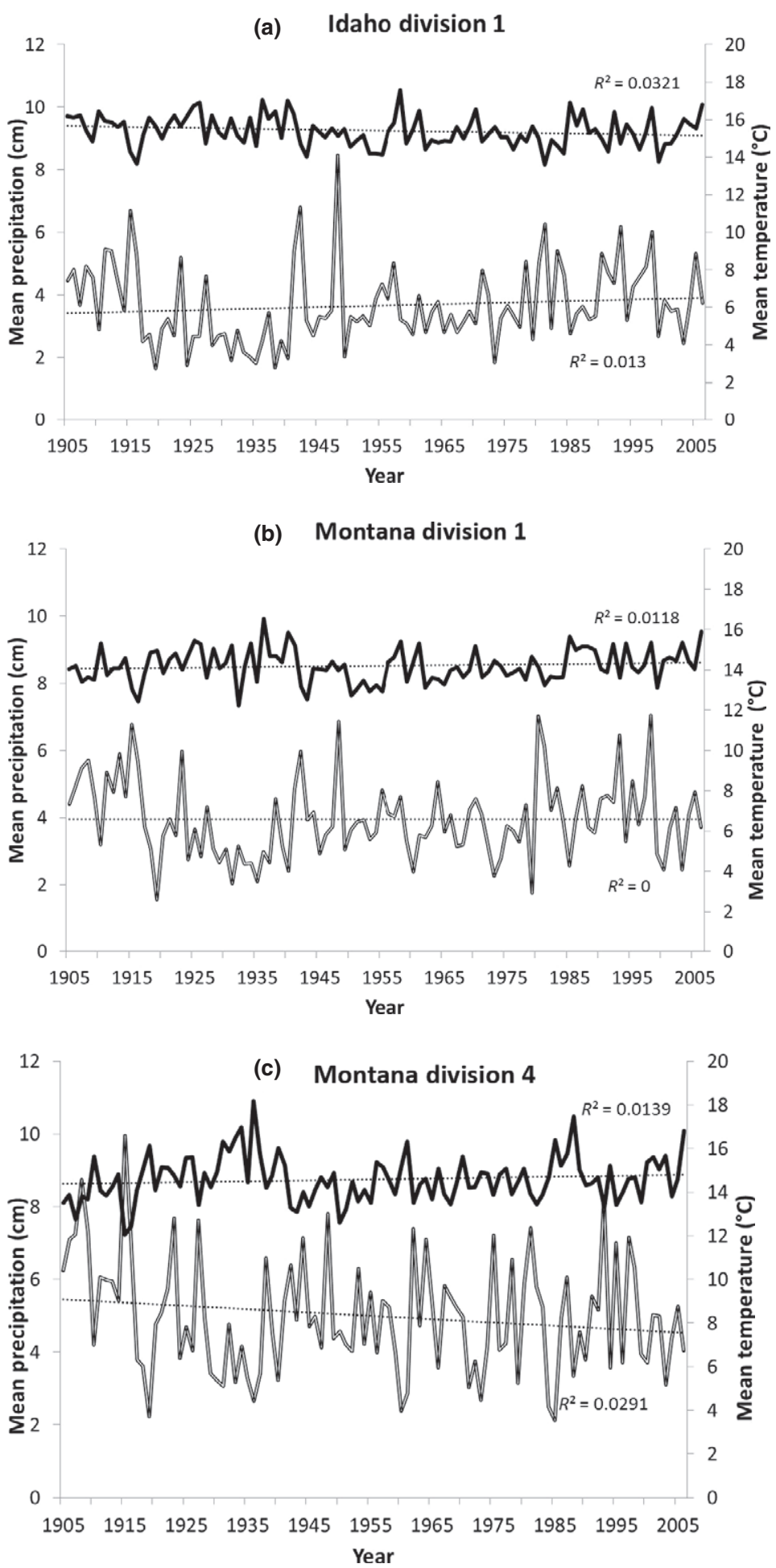

Figure 3 Yearly values of mean May to July temperature $\left({ }^{\circ} \mathrm{C}\right)$ and May to July precipitation $(\mathrm{cm})$ at: (a) Idaho Climate Division 1, (b) Montana Climate Division 1, and (c) Montana Climate Division 4, 19052006 within the northern Rocky Mountains, USA. The dotted line is a linear trend line with associated $R^{2}$ values. All linear trends were non-significant $(P>0.05)$. Thick black line: temperature; thick open line: precipitation; dotted lines: linear trends. drought in the northern Rockies in the 1930s (Fig. 4). During the 1930s, mean July PDSI values for Montana Climate Division 4 (Fig. 2) were -3.6 , with 9 of 10 years having PDSI values $<0$. Similar mean July PDSI conditions occurred for Idaho Climate Division $1(-2.2,9 / 10$ years $)$ and Montana Climate Division 1 ( $-2.7,9 / 10$ years). While others have identified some level of differential growth/climate responses for PIPO and PSME (e.g. Watson \& Luckman, 2002), our results here using BAI and from a prior study (Soule \& Knapp, 2013) examining relationships between climate and standardized radial growth rates for the complete chronologies developed at the 14 study sites demonstrate there are no discernible differences between species. We find that the magnitude and direction of the strongest climatic responses for PIPO and PSME are consistent among seven different sites with a variety of topoedaphic conditions. 
Table 3 Spearman correlations ( $P$-values) from each study site (northern Rocky Mountains, USA) of basal area increment (BAI) from ponderosa pine (Pinus ponderosa var. ponderosa) and Douglas-fir (Pseudotsuga menziesii var. glauca) trees with time (via pentad 1850-2005 ${ }^{\mathrm{a}}$ ), intrinsic water use efficiency (iWUE) with time (via pentad 1850-2005), and Spearman correlations between BAI and iWUE with significant relationships $(P<0.05)$ in bold (see Table 1 for complete study site names and chronology details).

\begin{tabular}{|c|c|c|c|}
\hline SITE & $r_{\mathrm{s}}$ BAI with time & $r_{\mathrm{s}}$ iWUE with time & $r_{\mathrm{s}} \mathrm{BAI} / \mathrm{iWUE}$ \\
\hline WCR & $0.287(0.111)$ & $0.719(0.000)$ & $0.055(0.763)$ \\
\hline WCD & $0.522(0.000)$ & $0.773(0.000)$ & $0.548(0.001)$ \\
\hline FLR & $0.601(0.000)$ & $0.801(0.000)$ & $0.466(0.008)$ \\
\hline FLD & $0.720(0.000)$ & $0.815(0.000)$ & $0.600(0.000)$ \\
\hline RCR & $0.072(0.696)$ & $0.667(0.000)$ & $-0.115(0.529)$ \\
\hline RCD & $0.446(0.011)$ & $0.916(0.000)$ & $0.351(0.049)$ \\
\hline FCR & $0.870(0.000)$ & $0.910(0.000)$ & $0.785(0.000)$ \\
\hline FCD & $0.131(0.474)$ & $0.900(0.000)$ & $0.268(0.138)$ \\
\hline RKR & $-0.463(0.008)$ & $0.916(0.000)$ & $-0.523(0.002)$ \\
\hline RKD & $-0.533(0.002)$ & $0.741(0.002)$ & $-0.573(0.001)$ \\
\hline BCR & $0.703(0.000)$ & $0.665(0.000)$ & $0.280(0.127)$ \\
\hline $\mathrm{BCD}$ & $-0.086(0.641)$ & $0.612(0.000)$ & $-0.116(0.528)$ \\
\hline CGR & $-0.139(0.447)$ & $0.840(0.000)$ & $-0.081(0.658)$ \\
\hline CGD & $-0.608(0.000)$ & $0.930(0.000)$ & $-0.666(0.000)$ \\
\hline $\mathrm{PIPO}^{\mathrm{b}}$ & $0.406(0.021)$ & $0.930(0.000)$ & $0.266(0.142)$ \\
\hline PSME & $0.135(0.462)$ & $0.895(0.000)$ & $0.008(0.965)$ \\
\hline
\end{tabular}

${ }^{a}$ The final pentad for BCR and FLR is 2000, thus $n=31$. For all other sites $n=32$.

${ }^{\mathrm{b}} \mathrm{PIPO}$ and PSME are the multi-site means.

Despite the physiological linkages that suggest trees should perform better in a $\mathrm{C}_{\mathrm{a}}$-rich environment, increasing rates of iWUE may not translate into enhanced radial growth (e.g. Gedalof \& Berg, 2010; Silva et al., 2010; Andreu-Hayles et al., 2011; Peñuelas et al., 2011; Silva \& Anand, 2013). Silva \& Anand (2013) propose a latitudinal control of the relationship, with higher latitude trees showing a positive radial growth response associated with the synergistic effects of $C_{a}$ enrichment and warming. Conversely, low-latitude trees are dominated by negative trends in radial growth with the suggestion that moisture stress induced by warming is more important than photosynthetic gains associated with increasing iWUE. Our results show that mixed growth responses can occur within a given geographical region (latitudinal zone). We found that both positive and negative radial growth trends occurred among our seven sites in the northern Rockies, and in the absence of any substantive increases in temperature in the region (Fig. 3, Table 3). However, BAI values for the seven-site means are remarkable for the consistency of positive values during the post-1950 period, particularly for PIPO (Fig. 4h). Positive values have occurred despite several pentads with droughts, including the severe drought of 2000-2004, which recorded 60 consecutive months of drought conditions in both Montana Climate Divisions 1 and 4. Thus, above-average radial growth occurred for both species, but particularly for PIPO, during the period with the highest $C_{a}$ values yet without significant changes to the climatic drivers of radial growth (Soulé \& Knapp, 2013).
Some (Silva \& Anand, 2013; Silva \& Horwath, 2013) have argued that observed increases in iWUE in trees are not a physiological response, but occurred independently of $\delta^{13} \mathrm{C}$ changes because of continual increases in $\mathrm{C}_{\mathrm{a}}$. In contrast, Brooks (2013) argues that what is being observed is a physiological response, thus heterogeneity in iWUE rates should be expected in natural settings. Several studies have reported a levelling of iWUE at the end of the record (e.g. Waterhouse et al., 2004; Gagen et al., 2011; Wang et al., 2012) or no change in iWUE during the 20th century (Marshall \& Monserud, 1996), while others have found significant positive trends in iWUE (Bert et al., 1997; Feng, 1999; Tang et al., 1999; Arneth et al., 2002; Saurer et al., 2004; Liu et al., 2007; Knapp \& Soulé, 2011). Results from our 14 study sites are consistent with the studies reporting increases, and at all sites the highest iWUE was recorded in one of the last two pentads.

While PSME currently exhibits greater iWUE than PIPO, PIPO is increasing iWUE more rapidly and the differences between the two species are becoming smaller (Fig. 5). Our sampling strategy minimizes the possibility that some withinsite factor such as increasing soil moisture or greater nutrient availability has preferentially influenced iWUE in one species more greatly than the other. Further, both species have similar climate responses, so the differential temporal response in iWUE is unlikely to be climatically driven, but may reflect inherent physiological differences between species. Physiological differences between these species that could impact iWUE were identified by Stout \& Sala $(2003$, p. 48) who determined that PIPO had 'greater stomatal sensitivity to water stress, shifts in biomass allocation and enhanced capacity to store water' relative to PSME, and concluded that PIPO is more drought resistant. Similarly, Marshall \& Monserud (2006) found differences in stable oxygen-isotope ratios $\left(\delta^{18} \mathrm{O}\right)$ between co-occurring PIPO and PSME. PIPO became more $\delta^{18} \mathrm{O}$-enriched through time and expressed no autocorrelation with lagged $\delta^{18} \mathrm{O}$ values, inferring a strong dependence on near-surface water availability. These results contrast with the responses of PSME and illustrate the differential behaviour between the two species through time under near-identical settings.

For the region as a whole, a significant differential response between PIPO BAI and PSME BAI occurred temporally (Figs $4 \mathrm{~h} \& 5$ ). As the difference in iWUE between PIPO and PSME has also been decreasing in recent decades (Fig. 6h), it raises questions of whether the two are causally related: that is, have improvements in iWUE for PIPO relative to PSME been responsible for the shift in BAI ratio, and if so, could there be longer-term ecosystem implications related to the increasing performance of PIPO relative to PSME? While the comparative changes in BAI between species began during the 1930s drought, a response expected via the findings of Stout \& Sala (2003), these changes continued through to the end of the record and represent a reversal of the relative growth rates during 1850-1930 (Fig. 4h).

In summary, both PSME and PIPO have recorded exponentially increasing iWUE since the mid-19th century and this response occurred at all sites, suggesting a pan-regional effect. 

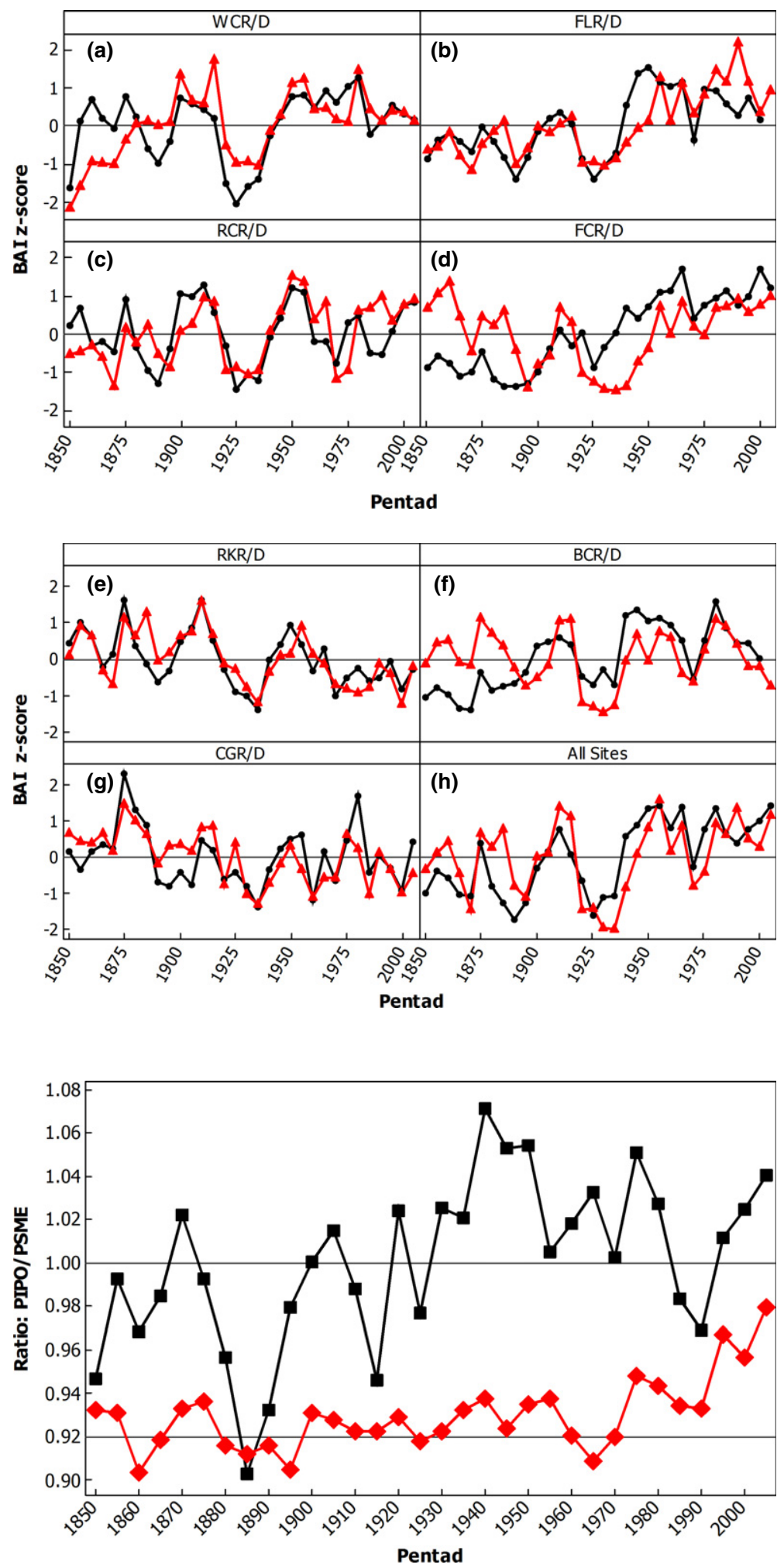

Figure 4 Pentadal basal-area index values (BAI) during AD 1850-2005 (except for BCR and FLR, which end in 2000) for: (a) WCR/WCD, (b) FLR/FLD, (c) RCR/RCD, (d) FCR/FCD, (e) RKR/RKD, (f), BCR/ $\mathrm{BCD}$, (g) CGR/CGD, and (h) the seven-site means (five-sites for the 2005 pentad) for ponderosa pine (Pseudotsuga menziesii var. glauca; PSME) and Douglas-fir (Pinus ponderosa var. ponderosa; PIPO) trees growing in the northern Rocky Mountains, USA. Red lines with triangle markers represent PSME and black lines with circle markers represent PIPO.

Figure $\mathbf{5}$ The black line with square markers shows the ratio of ponderosa pine (Pinus ponderosa var. ponderosa; PIPO) basal area index (BAI) to Douglas-fir (Pseudotsuga menziesii var. glauca; PSME) radial tree growth, by pentad, within the northern Rocky Mountains, USA. The ratio was created by adding a constant of 10 to the pentadal standardized values for the seven-site (five-site for the 2005 pentad) mean, then dividing PIPO growth by PSME growth. The red line with diamond markers shows the same ratio for intrinsic water-use efficiency (iWUE).
Overall, PIPO experienced greater iWUE and BAI increases than PSME, demonstrating that differential responses to environmental drivers occurred for these species with geographically extensive and overlapping ranges. Further, the difference in iWUE between species has markedly decreased during the past 30 years concurrent with the highest levels of $\mathrm{C}_{\mathrm{a}}$, with PIPO rates increas- ing faster than those of PSME. Tree growth and iWUE are important components of forest dynamics that respond to changing climate and atmospheric conditions (Aber et al., 2001; Ollinger et al., 2008), but the full extent of ecosystem modification potentially extends to changing composition, density, spatial extent, biomass accumulation and carbon sequestration 
Figure 6 Pentadal values $(\mu \mathrm{mol} / \mathrm{mol})$ of intrinsic water-use efficiency (iWUE) from 1850 to 2005 (except BCR and FLR which end in 2000) for: (a) WCR/WCD, (b) FLR/ FLD, (c) RCR/RCD, (d) FCR/FCD, (e) RKR/RKD, (f), BCR/BCD, (g) CGR/CGD, and $(\mathrm{h})$ the seven-site means (five-site for the 2005 pentad) for ponderosa pine (Pseudotsuga menziesii var. glauca; PSME) and Douglas-fir (Pinus ponderosa var. ponderosa; PIPO) trees growing in the northern Rocky Mountains, USA. Red lines with triangle markers represent PSME, while black lines with circle markers represent PIPO.

(Bonan, 2008). Given the extensive geographical range and economic value of PSME and PIPO forests to North American forestry, any substantive change in forest dynamics should have both ecological and economic implications. Our findings may extend to other ecosystems with co-occurring and co-dominant trees experiencing differential responses to changing environmental conditions.

\section{ACKNOWLEDGEMENTS}

The research was funded by grant no. 0851081 from the National Science Foundation, USA. We thank Justin Maxwell, Phil White and David Austin for their assistance with data collection and laboratory work. Our primary contact in the United States Forest Service, Steve Shelly, provided valuable assistance with the fieldwork portion of the study. We also thank Jack Williams and three referees for their constructively critical comments.

\section{REFERENCES}

Aber, J., Neilson, R.P., McNulty, S., Lenihan, J.M., Bachelet, D. \& Drapek, R.J. (2001) Forest processes and global environmental change: predicting the effects of individual and multiple stressors. BioScience, 51, 735-751.
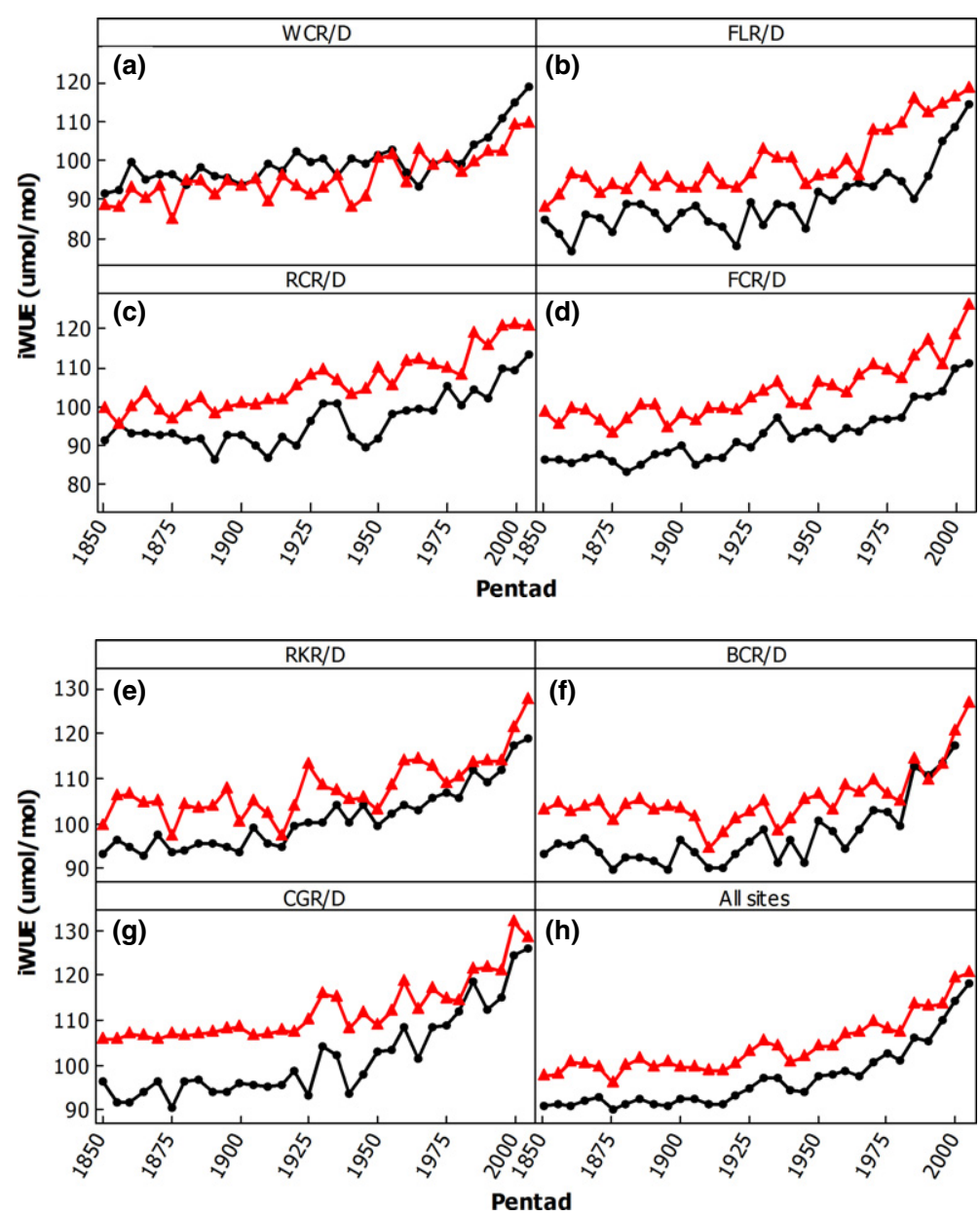

Adams, H.S., Stephenson, S.L., Blasing, T.J. \& Duvick, D.N. (1985) Growth-trend declines of spruce and fir in midAppalachian subalpine forests. Environmental and Experimental Botany, 25, 315-325.

Andreu-Hayles, L., Planells, O., Gutiérrez, E., Muntan, E., Helle, G., Anchukaitis, K.I. \& Schleser, G.H. (2011) Long tree-ring chronologies reveal 20th century increases in water-use efficiency but no enhancement of tree growth at five Iberian pine forests. Global Change Biology, 17, 20952112.

Arneth, A., Lloyd, J., Santruckova, H., Bird, M., Girgoryev, S., Kalaschnikov, Y.N., Gleixner, G. \& Schulze, E. (2002) Response of central Siberian Scots pine to soil water deficit and long-term trends in atmospheric $\mathrm{CO}_{2}$ concentration. Global Biogeochemical Cycles, 16, doi:10.1029/2000GB001374.

Bert, D., Leavitt, S. \& Dupouey, J.-L. (1997) Variations of wood $\delta^{13} \mathrm{C}$ and water-use efficiency of Abies alba during the last century. Ecology, 78, 588-1596.

Bonan, G.B. (2008) Forests and climate change: forcings, feedbacks, and the climate benefits of forests. Science, 320, 1444-1449.

Brooks, J.R. (2013) RE: Calculating iWUE from carbon isotopes can overestimate the physiologic response to rising atmospheric $\mathrm{CO}_{2}$. PLoS ONE, 8, 353089. doi:10.1371/journal.pone.0053089. 
Cook, E.R. \& Peters, K. (1997) Calculating unbiased tree-ring indices for the study of climatic and environmental change. The Holocene, 7, 361-370.

Coplen, T. (1996) New guidelines for reporting stable hydrogen, carbon and oxygen isotope-ratio data. Geochimica et Cosmochimica Acta, 602, 3359-3360.

Dawes, M.A., Hattenschwiler, S., Bebi, P., Hagedorn, F., Handa, I.T., Korner, C. \& Rixen, C. (2011) Species-specific tree growth responses to 9 years of $\mathrm{CO}_{2}$ enrichment at the alpine treeline. Journal of Ecology, 99, 383-394.

Earle, C.J. (2013) The Gymnosperm Database. Available at: http://www.conifers.org/index.php (accessed July 2013).

Ehleringer, J.R. \& Cerling, T.E. (1995) Atmospheric $\mathrm{CO}_{2}$ and the ratio of intercellular to ambient $\mathrm{CO}_{2}$ concentrations in plants. Tree Physiology, 15, 105-111.

Evenden, A.G., Moeur, M., Shelly, J.S., Kimball, S.F. \& Wellner, C.A. (2001) Research Natural Areas on National Forest System lands in Idaho, Montana, Nevada, Utah, and Western Wyoming: a guidebook for scientists, managers, and educators. General Technical Report RMRS-GTR-59. United States Department of Agriculture, Forest Service, Ogden, UT.

Farquhar, G.D., Ehleringer, J.R. \& Hubick, K.T. (1989) Carbon isotope discrimination and photosynthesis. Annual Review of Plant Physiology and Plant Molecular Biology., 40, 503-537.

Feng, X. (1999) Trends in intrinsic water-use efficiency of natural trees for the past 100-200 years: a response to atmospheric concentration. Geochimica et Cosmochimica Acta, 63, 1891-1903.

Fritts, H.C. (1976) Tree rings and climate. Academic Press, London.

Gagen, M.C., Finsinger, W., Wagner-Cremer, F., McCarroll, D., Loader, N.J., Robertson, I., Jalkanens, R., Young, G. \& Kirchheffer, A. (2011) Evidence of changing intrinsic wateruse efficiency under rising atmospheric $\mathrm{CO}_{2}$ concentrations in boreal Fennoscandia from subfossil leaves and tree ring $\delta^{13} \mathrm{C}$ ratios. Global Change Biology, 17, 1064-1072.

Gedalof, Z. \& Berg, A.A. (2010) Tree ring evidence for limited $\mathrm{CO}_{2}$ fertilization of forests over the 20th century. Global Biogeochemical Cycles, 24, doi:10.1029/2009GB003699.

Grissino-Mayer, H.D. (2001) Evaluating crossdating accuracy: a manual and tutorial for the computer program COFECHA. Tree-Ring Research, 57, 205-221.

Holmes, R.L. (1983) Computer-assisted quality control in tree-ring dating and measurement. Tree-Ring Bulletin, 43, 69-78.

Huang, J.-G., Bergeron, Y., Denneler, B., Berninger, F. \& Tardif, J. (2007) Response of forest trees to increased atmospheric $\mathrm{CO}_{2}$. Critical Reviews in Plant Science, 26, 265-283.

Idso, K.E. \& Idso, S.B. (1994) Plant responses to atmospheric $\mathrm{CO}_{2}$ enrichment in the face of environmental constraints: a review of the past 10 years' research. Agricultural and Forest Meteorology, 69, 153-203.

Keeling, C.D., Piper, S.C., Bacastow, R.B., Wahlen, M., Whorf, T.P., Heimann, M. \& Meijer, H.A. (2001) Exchanges of atmospheric $\mathrm{CO}_{2}$ and ${ }^{13} \mathrm{CO}_{2}$ with the terrestrial biosphere and oceans from 1978 to 2000. Global aspects, SIO Reference Series, No. 01-06. Scripps Institution of Oceanography, San Diego, CA.

Knapp, P.A. \& Soulé, P.T. (2011) Increasing water-use efficiency and age-specific growth responses of old-growth ponderosa pine trees in the Northern Rockies. Global Change Biology, 17, 631-641.

Knapp, P.A., Soulé, P.T. \& Maxwell, J.T. (2013) Mountain pine beetle selectivity in old-growth ponderosa pine forests, Montana, USA. Ecology and Evolution, 3, 1141-1148.

Koutavas, A. (2013) $\mathrm{CO}_{2}$ fertilization and enhanced drought resistance in Greek firs from Cephalonia Island, Greece. Global Change Biology, 19, 529-539.

Leavitt, S. \& Danzer, S. (1993) Method for batch processing small wood samples to holocellulose for stable-carbon isotope analysis. Analytical Chemistry, 65, 87-89.

Lee, E.H. \& Hogsett, W.E. (2001) Interpolation of temperature and non-urban ozone exposure at high spatial resolution over the western United States. Climate Research, 18, 163-179.

Linares, J.C. \& Camarero, J.J. (2012) From pattern to process: linking intrinsic water-use efficiency to drought-induced forest decline. Global Change Biology, 18, 1000-1015.

Liu, X., Shao, X., Liang, E., Zhao, L., Chen, T., Qin, D. \& Ren, J. (2007) Species dependent responses of juniper and spruce to increasing $\mathrm{CO}_{2}$ concentration and to climate in semi-arid and arid areas of northwestern China. Plant Ecology, 193, 195-209.

Lüthi, D., Le Floch, M., Bereiter, B., Blunier, T., Barnola, J.-M., Siegenthaler, U., Raynaud, D., Jouzel, J., Fischer, H., Kawamur, K. \& Stocker, T.F. (2008) High-resolution carbon dioxide concentration record 650,000-800,000 years before present. Nature, 453, 379-382.

Marshall, J.D. \& Monserud, R.A. (1996) Homeostatic gasexchange parameters inferred from ${ }^{13} \mathrm{C} /{ }^{12} \mathrm{C}$ in tree rings of conifers. Oecologia, 105, 13-21.

Marshall, J.D. \& Monserud, R.A. (2006) Co-occurring species differ in tree ring $\delta^{18} \mathrm{O}$ trends. Tree Physiology, 26, 1055-1066.

McCarroll, D. \& Loader, N. (2004) Stable isotopes in tree rings. Quaternary Science Reviews, 23, 771-801.

Morgan, J.A., Pataki, D.E., Körner, C., Clark, H., Del Gross, S. J., Grunzweig, J.M., Knapp, A.K., Mosier, A.R., Newton, P.C.D., Niklaus, P.A., Nippert, J.B., Nowak, R.S., Parton, W.J., Polley, H.W. \& Shaw, M.R. (2004) Water relations in grassland and desert ecosystems exposed to elevated atmospheric $\mathrm{CO}_{2}$. Oecologia, 140, 11-25.

Ollinger, S.V., Goodale, C.L., Hayhoe, K. \& Jenkins, J.P. (2008) Potential effects of climate change and rising $\mathrm{CO}_{2}$ on ecosystem processes in northeastern U.S. forests. Mitigation and Adaptation Strategies for Global Change, 13, 467-485.

Palmer, W. (1965) Meteorological drought. US Government Printing Office, Washington, DC.

Peñuelas, J., Hunt, J.M., Ogaya, R. \& Jump, A.S. (2008) Twentieth century changes of tree-ring $\delta^{13} \mathrm{C}$ at the southern range-edge of Fagus sylvatica: increasing water-use efficiency does not avoid the growth decline induced by warming at low altitudes. Global Change Biology, 14, 1076-1088. 
Peñuelas, J., Canadell, J.G. \& Ogaya, R. (2011) Increased water-use efficiency during the 20th century did not translate into enhanced tree growth. Global Ecology and Biogeography, 20, 597-608.

Phipps, R.L. (1985) Collecting, preparing, crossdating, and measuring tree increment cores. US Geologic Survey WaterResources Investigations Report 85-4148, Washington, DC.

Piñol, J. \& Sala, A. (2000) Ecological implications of xylem cavitation for several Pinaceae in the Pacific Northern USA. Functional Ecology, 14, 538-545.

Salzer, M.W., Hughes, M.K., Bunn, A.G. \& Kipfmueller, K.F. (2009) Recent unprecedented tree-ring growth in bristlecone pine at the highest elevations and possible causes. Proceedings of the National Academy of Sciences USA, 106, 20348-20353.

Saurer, M., Siegwolf, R. \& Schweingruber, F. (2004) Carbon isotope discrimination indicates improving water-use efficiency of trees in northern Eurasia over the last 100 years. Global Change Biology, 10, 2109-2120.

Silva, L.C. \& Anand, M. (2013) Probing for the influence of atmospheric $\mathrm{CO}_{2}$ and climate change on forest ecosystems across biomes. Global Ecology and Biogeography, 22, 83-92.

Silva, L.C. \& Horwath, W.R. (2013) Explaining global increases in water use efficiency: why have we overestimated responses to rising atmospheric $\mathrm{CO}_{2}$ in natural forest ecosystems? PLoS ONE, 8, 353089. doi:10.1371/journal. pone.0053089.

Silva, L.C., Anand, M. \& Leithead, M.D. (2010) Recent widespread tree growth decline despite increasing atmospheric $\mathrm{CO}_{2}$. PLoS ONE, 5, 11543. doi:10.1371/journal.pone.0011543.

Soulé, P.T. \& Knapp, P.A. (2011) Radial growth and increased water-use efficiency for ponderosa pine tree in three regions in the western United States. The Professional Geographer, 63, 1-13.

Soulé, P.T. \& Knapp, P.A. (2013) Radial growth rates of two co-occurring coniferous trees in the northern Rockies during the past century. Journal of Arid Environments, 94, 87-95.

Speer, J.H. \& Holmes, R.L. (2004) Effects of pandora moth outbreaks on ponderosa pine wood volume. Tree-Ring Research, 60, 69-76.

Speer, J.H., Swetnam, T.W., Wickman, B.E. \& Youngblood, A. (2001) Changes in pandora moth outbreak dynamics during the past 622 years. Ecology, 82, 669-697.

Stanton, S. (2007) Effects of dwarf mistletoe on climate response of mature ponderosa pine trees. Tree Ring Research, 63, 69-80.

Sternberg, L. (1989) Oxygen and hydrogen isotope measurements in plant cellulose. Modern methods in plant analysis (ed. by H.F. Linskens and J.F. Jackson), pp. 89-98. Springer-Verlag, Berlin.

Stout, D.L. \& Sala, A. (2003) Xylem vulnerability to cavitation in Pseudotsuga menziesii and Pinus ponderosa from contrasting habitats. Tree Physiology, 23, 43-50.

Tang, K., Feng, X. \& Funkhouser, G. (1999) The $\delta^{13} \mathrm{C}$ of trees in full-bark and strip-bark bristlecone pine trees in the White Mountains of California. Global Change Biology, 5, 33-40.

Tognetti, R., Longobucco, A., Miglietta, F. \& Raschi, A. (1998) Transpiration and stomatal behaviour of Quercus ilex plants during the summer in a Mediterranean carbon dioxide spring. Plant, Cell and Environment, 21, 613-622.

Tyson, P., Odada, E., Schulze, R. \& Vogel, C. (2002) Regional-global linkages: southern Africa. Global-regional linkages in the Earth system (ed. by P. Tyson, R. Fuchs and F. Corbin), pp. 3-73. Springer-Verlag, Berlin.

Wang, W., Liu, X., An, W., Xu, G. \& Zeng, X. (2012) Increased intrinsic water-use efficiency during a period with persistent decreased tree radial growth in northwestern China: causes and implications. Forest Ecology and Management, 275, 14-22.

Waterhouse, J.S., Switsur, V.R., Barker, A.C., Carter, A.H.C., Hemming, D.L., Loader, N.J. \& Robertson, I. (2004) Northern European trees show a progressively diminishing response to increasing atmospheric carbon dioxide concentrations. Quaternary Science Reviews, 23, 803-810.

Watson, E. \& Luckman, B.H. (2002) The dendroclimatic signal in Douglas-fir and ponderosa pine tree-rings chronologies from the southern Canadian Cordillera. Canadian Journal of Forest Research, 32, 1858-1874.

Wullschleger, S.D., Tschaplinski, T.J. \& Norby, R.J. (2002) Plant water relations at elevated $\mathrm{CO}_{2}-$ implications for water limited environments. Plant, Cell, and Environment, 25, 319-331.

WWPA (2013) Ponderosa Pine Species Facts. Western Wood Products Association. Available at: http://www2.wwpa.org/ WESTERNSPECIES/PonderosaPine/tabid/298/Default.aspx (accessed July 2013).

Yamaguchi, D. (1991) A simple method for cross-dating increment cores from living trees. Canadian Journal of Forest Research, 21, 414-416.

Zhang, J. \& Marshall, J.D. (1994) Population differences in water-use efficiency of well-watered and water-stressed western larch seedlings. Canadian Journal of Forest Research, 24, 92-99.

\section{BIOSKETCHES}

Peter Soulé is a professor in the Department of Geography and Planning at Appalachian State University. Over the past decade he has been examining issues related to the driving climatic and atmospheric forces behind observed changes in western US forest ecosystems.

Paul Knapp is a professor and director of the Carolina Tree-Ring Science Laboratory in the Department of Geography at the University of North Carolina-Greensboro. His interests have focused on the palaeoecological dynamics of western US forests.

Editor: Jack Williams 